\title{
Correction to: Development of an intervention to facilitate implementation and uptake of diabetic retinopathy screening
}

Fiona Riordan ${ }^{1 *}$, Emmy Racine ${ }^{1}$, Eunice T. Phillip ${ }^{1}$, Colin Bradley ${ }^{2}$, Fabiana Lorencatto ${ }^{3}$, Mark Murphy ${ }^{4}$, Aileen Murphy ${ }^{5}$, John Browne', Susan M. Smith" Patricia M. Kearney ${ }^{1}$ and Sheena M. McHugh ${ }^{1}$

\section{Correction to: Implementation Sci (2020) 15:34} https://doi.org/10.1186/s13012-020-00982-4

Following the publication of the original article [1], the authors realised there were two errors in Additional file 9: Figure S1. The file should have included a footnote clarifying that the total number of people who completed questionnaires was 30 (13 patients and 17 health care professionals). 'Suppl. Figure 1 (d) - Feasible' was a copy of 'Suppl. Figure 1 (e) - Feasible'. The correct file has been included with this correction article.

\section{Supplementary information}

Supplementary information accompanies this paper at https://doi.org/10. 1186/s13012-020-01026-7.

Additional file 9.
Published online: 30 July 2020

\section{Reference}

1. Riordan F, Racine E, Phillip ET, et al. Development of an intervention to facilitate implementation and uptake of diabetic retinopathy screening. Implementation Sci. 2020;15:34 https://doi.org/10.1186/s13012-020-00982-4.

\begin{abstract}
Author details
'School of Public Health, University College Cork, Western Gateway Building, Western Rd, Cork, Ireland. ${ }^{2}$ Department of General Practice, University College Cork, Cork, Ireland. ${ }^{3}$ Centre for Behaviour Change, University College London, London, England. ${ }^{4}$ Department of General Practice, Royal College of Surgeons of Ireland, Dublin, Ireland. ${ }^{5}$ Department of Economics, Cork University Business School, University College Cork, Cork, Ireland.
\end{abstract}

The original article can be found online at https://doi.org/10.1186/s13012020-00982-4.

* Correspondence: fiona.riordan@ucc.ie

${ }^{1}$ School of Public Health, University College Cork, Western Gateway Building, Western Rd, Cork, Ireland

Full list of author information is available at the end of the article

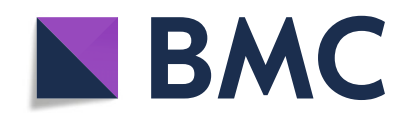

(c) The Author(s). 2020 Open Access This article is licensed under a Creative Commons Attribution 4.0 International License, which permits use, sharing, adaptation, distribution and reproduction in any medium or format, as long as you give appropriate credit to the original author(s) and the source, provide a link to the Creative Commons licence, and indicate if changes were made. The images or other third party material in this article are included in the article's Creative Commons licence, unless indicated otherwise in a credit line to the material. If material is not included in the article's Creative Commons licence and your intended use is not permitted by statutory regulation or exceeds the permitted use, you will need to obtain permission directly from the copyright holder. To view a copy of this licence, visit http://creativecommons.org/licenses/by/4.0/. The Creative Commons Public Domain Dedication waiver (http://creativecommons.org/publicdomain/zero/1.0/) applies to the data made available in this article, unless otherwise stated in a credit line to the data. 